\title{
PREPARATION AND EVALUATION OF YOGHURT PRODUCED USING SWEET LUPINE, CHICKPEA FLOUR AND THEIR DERIVATIVES
}

\author{
Ashraf I. Nagib*, Eshak M. El - Hadidy, *and Emad S. Shaker*** \\ * Food Technol. Res. Inst., Agric. Res. Center, Giza, Egypt \\ ** Agricultural Chemistry Dept., Minia University, Egypt \\ ABSTRACT
}

Sweet lupine (L) and chickpea (C) flour, protein concentrate (PC), protein isolate (PI) and fibrous residue (FR) have been examined for their properties and used in making yoghurt. The chemical analysis showed higher protein content for sweet lupine (88.32 and $64.52 \%$ for PI and PC, respectively) than chickpea (83.02 and $57.49 \%$ for PI and PC, respectively). Similar order has been noticed for protein solubility using different solvents. The crude fiber content was higher in chickpea (7.32 and $0.32 \%$ for PC and PI, respectively) than lupine (4.20 and 0.18 for $\mathrm{PC}$ and $\mathrm{PI}$, respectively).

The sensory evaluation revealed an improvement in the color, texture and appearance of yoghurt made using $0.25 \%$ CPC. Moreover, CPI improved the color, odor, texture and appearance at 0.25 and $0.50 \%$. The different concentrations of LFR and CFR improved the color, texture and appearance. The microbiological analysis showed prospective results with using different concentrations of LPC, CPC, LPI and CPI. Where, the total bacterial count was decreased except for $0.25 \%$ LPC, The yeast and mould content was decreased as well except for $0.25 \%$ CPC. In all the tested samples, the coliform group was not detected.

Key words: Lupine, chickpea, protein concentrate, protein isolate, yoghurt.

\section{INTROUCTION}

Leguminous seeds are the most important protein sources for human nutrition, since leguminous seeds flour and their derivatives have been widely used by authors and scientists in industry to enhance the food product quality. The legume seeds are generally characterized by a relatively high content of protein which ranged between 20 to $40 \%$ (Hussein, 1999). The importance of legume seeds may due to the considerable amount of amino acids content. The chemical composition for lupine and chickpea flour have been widely investigated through several studies. Millan et al. (1995) reported that lupine flour contained 7.7, 44.60, 2.1, 4.2 and 8.2 \%, from the previous components, respectively. Mohamed and Duarte (1995) found that lupine flour contained $38 \%$ protein, $10 \%$ lipids and $4 \%$ ash. Sobihah (1998) reported that the total protein, N P N, ash, fat, total carbohydrate and crude fiber for lupine seed flour were as follows; 42.24, 1.19, 3.99, 11.14, 38.0 and 4.45\%, respectively. In another study, Hussein (1999) found that the chemical composition of three lupine seed varieties ranged from $33.7-40.78 \%$ protein, $10.03-11.98 \%$ oil, 2.1$3.8 \%$ ash and 45.5-51.82\% carbohydrate. Whereas, Youssef (1999) showed that contents of Lupinus termis from protein, fat, ash, carbohydrate and moisture were 44.63, 14.46, 3.26, 37.65 and 8.02\%, respectively. Also, ElNaggar (1997) showed that defatted lupine seed flour contained fat, protein, carbohydrate, crude fiber and ash as 1.42, 48.5, 28.06, 18.57 and 3.45\%, respectively.

Bencini (1986) stated that raw chickpea flour contained moisture, protein, oil, ash, fiber and total carbohydrate about 7.4, 21.37, 7.17, 2.98, 2.16 and $58.98 \%$, respectively. In the same while, Metry et al. (2003) mentioned that the mean values of protein, ether extract, carbohydrate, crude fiber and

Fayoum J. Agric. Res. \& Dev., Vol.20, No.1, January, 2006 
Ashraf I. Nagib, et al.,

ash for chickpea were $23.82,5.12,54.74,12.65$ and $6.72 \%$, respectively. Compared with sweet lupine, the chemical composition of raw seeds was protein $38.95 \%$, ether extract $11.84 \%$, carbohydrate $36.62 \%$, crude fiber $11.08 \%$ and ash $4.83 \%$.

The alkaline extraction and subsequent precipitation of the proteins at the isoelectric point is the most common way to prepare protein isolates in food industry. The low cost of the chemicals and relative simplicity of the apparatus required, make this option advantageous as compared to other producers such as the separation of proteins by ultrafiltration membrane (Berot and Davin, 1996).

The functionality of protein influences the physical characteristics, food quality and sensory properties of food, in which they are incorporated. Therefore, studying the functional properties of protein concentrates and isolates are essential in order to monitor their effectively in food products. Protein solubility, water holding capacity and fat binding ability are some of the major functional properties of protein that strongly affect their utilization (Lee et al., 1987 and Hung and Zayas, 1992).

The use of legume or their protein concentrate or isolate powders find an increasing application in the manufacturing of dairy products. This may be due to their low cost, functional advantages and medical effects (Al-Zaid et al., 1991; and Eskander and Jun, 1995). Metry et al. (2003) showed that skim milk powder could be replaced with chickpea flour, protein concentrate or isolate powder up to $3 \%$ and sweet lupine flour, protein concentrate or isolate powder by $1 \%$ in order to produce ice-cream with good flavor, texture and melting quality.

In this research, the chemical composition and microbiological quality of sweet lupine and chickpea flour, protein isolate, concentrate and fibrous residue were investigated. The applied part had been fulfilled to increase the nutritional value of yoghurt, using sweet lupine and chickpea protein derivatives.

\section{MATERIALS AND METHODS \\ Materials:}

Fresh buffalo milk was obtained from a private farm to prepare the yoghurt. Sweet lupine (L) and chickpea (C) seeds were purchased from local markets.

\section{Methods:}

1. Preparation of sweet lupine, chickpea flour and their derivatives:

(a) Sweet lupine flour (Lupinus termis) and chickpea flour (Cicer arietimum) were prepared according to Hung and Nithianandan (1993), the seeds were washed and air dried at $35-40^{\circ} \mathrm{C}$ for 3 days. Then, they were ground using blender and stored in refrigerator until used.

(b) Preparation of protein isolate (PI) and protein concentrate (PC) and fibrous residue (FR) are presented in Figure (1).

\section{Chemical analysis:}

Legume flours (sweet lupine and chickpea) and their derivatives were chemically analyzed (moisture, ash, crude protein, ether extract and crude fiber) according to A.O.A.C. (1995). While, hydrolysable carbohydrate was determined as glucose according to Smith (1969). Protein solubility of PC and PI for lupine and chickpea was estimated in different solvents according to ElAdawy (1986) and in sodium chloride by concentration procedure according to King et al. (1985). 


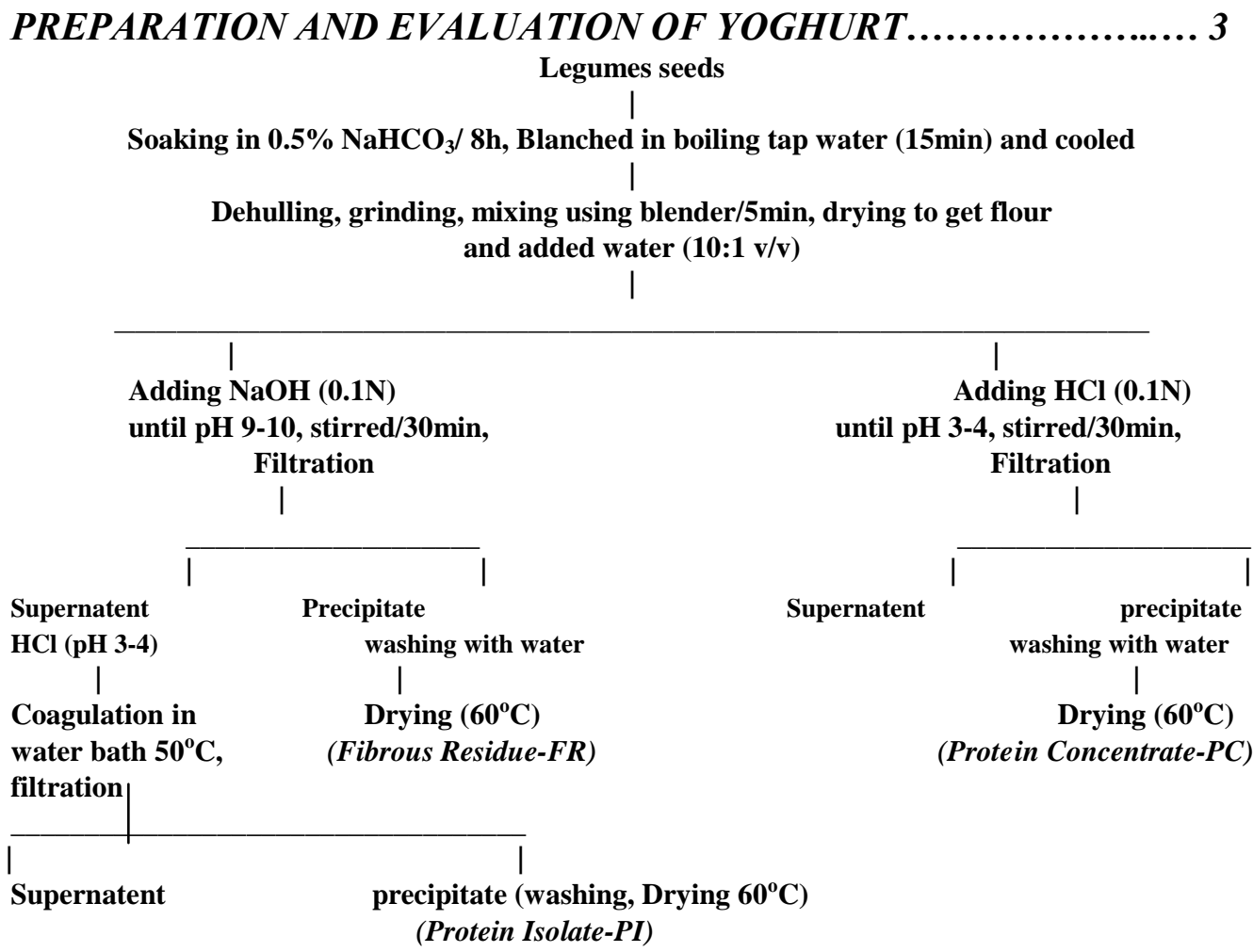

Figure 1: Diagram illustrates the preparation of legumes flour, protein concentrate, protein isolate and fibrous residue.

\section{Preparation of Yoghurt:}

Buffalo milk was heated in water bath at $90^{\circ} \mathrm{C} / 15 \mathrm{~min}$ before cooling to approximately $45^{\circ} \mathrm{C}$. The milk was inoculated with $2 \%$ yoghurt starter $(S$. thermophilus: L. delbreuckii ssp, 1:1). The inoculated milk was mixed with $0.25,0.50$ or $0.75 \%(\mathrm{~W} / \mathrm{V})$ of lupine or chickpea protein concentrates or isolates, and thoroughly homogenated and then filled in plastic containers and kept in thermostatically controlled incubator at $42^{\circ} \mathrm{C}$ until complete coagulation.

\section{Sensory evaluation of yoghurt fortified with legumes and their derivatives:}

The sensory evaluation of yoghurt fortified with sweet lupine and chickpea derivatives; PI, PC and FR were carried out by 10 panelists from the staff members at the Food Technol. Res. Inst., Agric. Res. Center, Giza, Egypt. Using evaluation scheme proposed by Saldamli et al. (1991). Statistical analysis of data was carried out according to the procedure described by Snedecor and Cochran (1973) and Gomiz and Gomez (1984). 5. Microbiological evaluation of yoghurt with legumes derivatives:

The resultant fresh yoghurt fortified with sweet lupine and chickpea (PI and PC) were microbiologically examined for total bacterial count (TBC), yeast and mould and coliform group as described in Difco (1985).

\section{RESULTS AND DISCUSSION}

\section{Chemical composition of legumes and their derivatives:}

Chemical composition of sweet lupine (L) and chickpea (C) and its derivatives on dry weight basis are recorded in Table (1). The results indicated that the crude protein content was high in the protein concentrates, it amounted to $64.52 \%$ in L and $57.49 \%$ in C, compared with dried flour $(38.95 \%, 23.82$,

Fayoum J. Agric. Res. \& Dev!, Vol.20, No.1, January, 2006 
Ashraf I. Nagib, et al.,

respectively). Moreover, the protein content in protein isolates was the highest for $\mathrm{L}$ and $\mathrm{C}$ being88.32\% and $83.02 \%$, respectively. Higher content of crude fiber was observed in L and C flour (11.08 and 12.65, respectively, followed by PC and finally by PI. The order for crude fiber was C $>\mathrm{L}$.

Table (1): Chemical composition \% for sweet lupine (L), chickpea flour (C)and their derivatives (Protein concentrate and protein isolates) on dry weight basis

\begin{tabular}{|l|c|c|c|c|c|c|}
\hline \multirow{2}{*}{ Constituents } & \multicolumn{2}{c|}{ Flour } & \multicolumn{2}{c|}{ Protein concentrate } & \multicolumn{2}{c|}{ Protein isolate } \\
\cline { 2 - 7 } \multicolumn{1}{c|}{ L } & C & L & C & L & C \\
\hline Moisture & 6.88 & 5.98 & 8.54 & 8.17 & 5.62 & 6.86 \\
\hline Crh & 4.83 & 6.72 & 3.64 & 3.22 & 2.81 & 4.15 \\
\hline Ether extract & 38.95 & 23.82 & 64.52 & 57.49 & 88.32 & 83.02 \\
\hline Total hydrolysable carbohydrate & 11.84 & 5.12 & 3.00 & 4.35 & 0.98 & 1.35 \\
\hline Crude fiber & 36.62 & 54.74 & 19.02 & 25.45 & 3.35 & 6.93 \\
\hline
\end{tabular}

These data are in agreement with Luck et al. (1995) who found $79.1 \%$ protein on dry matter for lupine protein isolate. Millan et al. (1995) found that the lupine protein isolate contained moisture, protein, lipid, carbohydrate, crude fiber and ash as $4.98,80.69,3.39,0.36,0.36$ and $3.58 \%$, respectively.

2. Protein solubility of legumes protein:

Protein solubility of lupine and chickpea as flour, protein concentrate and protein isolate were investigated using different solvents (Table 2). Protein solubility was higher for all the experiments when $\mathrm{NaOH} 0.1 \mathrm{M}$ was used, followed by $\mathrm{KCl}, \mathrm{NaCl}$ and finally by distilled water. This may be due to that water extracted only albumins, while both sodium and potassium chloride solubilized albumins and globulins and other fractions, such as prolamin and glutelins. Protein solubility was in the following descending order lupine >chickpea, and also PI $>$ PC $>$ legume flour.

Table (2): Protein solubility of flour, protein concentrates (PC) and isolates (PI) of lupine and chickpea (g/100g protein)

\begin{tabular}{|l|c|c|c|c|c|c|}
\hline \multicolumn{1}{|c|}{ Solvents } & \multicolumn{3}{|c|}{ Lupine } & \multicolumn{3}{c|}{ Chickpea } \\
\cline { 2 - 7 } & Flour & PC & PI & Flour & PC & PI \\
\hline Distilled water & 17.00 & 20.52 & 29.80 & 15.52 & 18.44 & 27.82 \\
NaCl 0.1M & 33.52 & 44.73 & 61.33 & 30.22 & 37.55 & 58.32 \\
KCl 0.1M & 36.08 & 52.87 & 65.24 & 31.84 & 38.27 & 60.04 \\
NaOH 0.1M & 39.22 & 60.54 & 73.62 & 37.25 & 43.95 & 69.37 \\
\hline
\end{tabular}

\section{Sensory evaluation of yoghurt fortified with legumes and their derivatives:}

Sensory evaluation of yoghurt fortified with different concentrations from sweet lupine and chickpea protein concentrate is presented in Table (3). Sweet lupine (LPC) showed effect in the yoghurt properties at different concentrations compared to control. 0.25 and $0.50 \%$ are better than $0.75 \%$ LPC, while $0.25 \%$ LPC showed non-significant changes compared with control but $0.5 \%$ LPC showed increase significant in texture and appearance.

On the other hand, chickpea protein concentrate (CPC) improved the color, texture and appearance at 0.25 compared with control. CPC as well showed effect in the texture at 0.25 and $0.75 \%$, and the appearance at $0.25 \%$ only. The treatments with legumes derivatives seem to have a greater effect on the texture to be more firm. It is obvious that legumes derivatives -especially CPC- improved color, texture and appearance at $0.25 \%$.

Fayoum J. Agric. Res. \& Dev., Vol.20, No.1, January, 2006 
PREPARATION AND EVALUATION OF YOGHURT.

Table (3): Sensory evaluation of yoghurt fortified with different concentrations of sweet lupine LPC and chickpea protein concentrate CPC

\begin{tabular}{|c|c|c|c|c|c|}
\hline Treatment & Color & Taste & Odor & Texture & Appearance \\
\hline Control & $8.4 \pm 0.52$ & $8.7 \pm 0.71$ & $8.8 \pm 0.63$ & $8.5 \pm 0.71$ & $8.3 \pm 0.67$ \\
\hline LPC & & & & & \\
$\mathbf{0 . 2 5 \%}$ & $8.2 \pm 0.99^{*}$ & $8.3 \pm 1.23^{*}$ & $8.3 \pm 0.82^{*}$ & $8.7 \pm 0.67 *$ & $8.6 \pm 0.52^{*}$ \\
$\mathbf{0 . 5 0 \%}$ & $8.1 \pm 1.25^{*}$ & $7.9 \pm 1.77^{*}$ & $8.4 \pm 1.43^{*}$ & $8.9 \pm 1.10^{* *}$ & $8.7 \pm 1.01^{* * *}$ \\
$\mathbf{0 . 7 5 \%}$ & $7.8 \pm 1.16^{* * *}$ & $7.4 \pm 1.87^{* *}$ & $7.5 \pm 1.43^{* *}$ & $8.7 \pm 1.11^{*}$ & $8.0 \pm 1.05^{*}$ \\
$\mathbf{L S D}(\boldsymbol{p}<\mathbf{0 . 0 5})$ & $\mathbf{0 . 5 7}$ & $\mathbf{0 . 5 6}$ & $\mathbf{0 . 5 5}$ & $\mathbf{0 . 1 6}$ & $\mathbf{0 . 3 2}$ \\
\hline $\mathbf{C P C}$ & & & & & \\
$\mathbf{0 . 2 5 \%}$ & $9.1 \pm 0.47^{* * *}$ & $8.3 \pm 0.87^{*}$ & $8.9 \pm 0.74^{*}$ & $9.1 \pm 0.70^{* * *}$ & $8.8 \pm 0.63^{* * *}$ \\
$\mathbf{0 . 5 0 \%}$ & $8.6 \pm 0.71^{*}$ & $7.8 \pm 1.12^{* *}$ & $8.2 \pm 1.03^{* *}$ & $8.6 \pm 0.69^{*}$ & $8.5 \pm 0.71^{*}$ \\
$\mathbf{0 . 7 5 \%}$ & $8.4 \pm 1.26^{*}$ & $7.8 \pm 1.80^{* *}$ & $8.1 \pm 1.29^{* *}$ & $8.8 \pm 1.03^{* * *}$ & $8.2 \pm 1.03^{*}$ \\
$\mathbf{L S D}(\boldsymbol{p}<\boldsymbol{0 . 0 5})$ & $\mathbf{0 . 3 3}$ & $\mathbf{0 . 4 4}$ & $\mathbf{0 . 4 1}$ & $\mathbf{0 . 2 6}$ & $\mathbf{0 . 2 6}$ \\
\hline
\end{tabular}

The values are mean of 10 panelists $( \pm$ SD).

$*$ Non-significant $\quad * *$ Decrease significant $\quad * * *$ Increase significant

The sensory evaluation of yoghurt fortified with protein isolate showed an enhancement for the organoleptic properties when using $0.25 \%, 0.5 \%$ and $0.75 \%$ in case of (LPI) or CPI compared to control. Sweet lupine protein isolate LPI showed an effect (Table 4) on the yoghurt texture at different concentrations compared to control. Only $0.25 \%$ LPI improved the yoghurt color and appearance. While, LPI improved the yoghurt color and appearance at 0.25 and $0.50 \%$. In the same table, chickpea protein isolate CPI improved the color and appearance at 0.25 and $0.50 \%$ and the texture at $0.75 \%$ compared to control.

Sweet lupine fibrous residue after isolated protein (LFR) showed effect (Table 5) on the yoghurt color, texture and appearance at different concentrations compared to control. $0.25 \%$ LFR improved the taste of yoghurt but non significant compared with control.

On the same trend, chickpea fibrous residue CFR improved the texture, appearance and color at different concentrations compared to control. At $0.75 \%$ CFR, the panelist started to detect taste improvement. $0.25 \%$ CFR enhanced the yoghurt odor.

Table (4): Sensory evaluation of yoghurt fortified with different concentrations of sweet lupine LPI and chickpea protein isolate CPI

\begin{tabular}{|c|c|c|c|c|c|}
\hline Treatment & Color & Taste & Odor & Texture & Appearance \\
\hline Control & $8.4 \pm 0.52$ & $8.7 \pm 0.71$ & $8.8 \pm 0.63$ & $8.5 \pm 0.71$ & $8.3 \pm 0.67$ \\
\hline LPI & & & & & \\
$\mathbf{0 . 2 5 \%}$ & $9.1 \pm 0.67 * * *$ & $8.2 \pm 1.09 *$ & $8.7 \pm 0.79 *$ & $8.9 \pm 0.77 *$ & $8.8 \pm 0.79 * * *$ \\
$\mathbf{0 . 5 0 \%}$ & $8.8 \pm 0.97 * * *$ & $8.0 \pm 1.27 *$ & $8.3 \pm 0.95 *$ & $9.0 \pm 0.94 * * *$ & $8.5 \pm 1.08^{*}$ \\
$\mathbf{0 . 7 5 \%}$ & $8.1 \pm 1.10^{*}$ & $7.1 \pm 1.39 * *$ & $7.7 \pm 1.06 * *$ & $8.8 \pm 0.79 *$ & $8.1 \pm 1.10^{*}$ \\
$\boldsymbol{L S D}(\boldsymbol{p}<\mathbf{0 . 0 5})$ & $\mathbf{0 . 4 4}$ & $\mathbf{0 . 6 7}$ & $\mathbf{0 . 5 0}$ & $\mathbf{0 . 2 2}$ & $\boldsymbol{0 . 3 0}$ \\
\hline CPI & & & & & \\
$\mathbf{0 . 2 5 \%}$ & $9.2 \pm 0.57$ & $8.9 \pm 6.0$ & $9.0 \pm 0.47$ & $8.8 \pm 0.63 *$ & $9.1 \pm 0.32 * * *$ \\
$\mathbf{0 . 5 0 \%}$ & $8.8 \pm 0.63$ & $8.3 \pm 0.87$ & $8.9 \pm 0.73$ & $8.8 \pm 0.93 *$ & $8.8 \pm 0.79 * * *$ \\
$\mathbf{0 . 7 5 \%}$ & $8.4 \pm 1.26$ & $7.7 \pm 1.22$ & $8.0 \pm 0.94$ & $9.1 \pm 0.74 * * *$ & $8.5 \pm 0.53 *$ \\
$\boldsymbol{L S D}(\boldsymbol{p}<\mathbf{0 . 0 5})$ & $\mathbf{0 . 3 8}$ & $\mathbf{0 . 5 3}$ & $\mathbf{0 . 4 6}$ & $\mathbf{0 . 2 5}$ & $\mathbf{0 . 3 5}$ \\
\hline
\end{tabular}

The values are mean of 10 panelists $( \pm \mathrm{SD})$.

$*$ Non-significant $\quad * *$ Decrease significant $\quad * * *$ Increase significant

Fayoum J. Agric. Res. \& Dev., Vol.20, No.1, January, 2006 
Ashraf I. Nagib, et al.,

Table (5): Sensory evaluation of yoghurt fortified with different concentrations of lupine LFR and chickpea fibrous residue CFR after isolated protein

\begin{tabular}{|c|c|c|c|c|c|}
\hline Treatment & Color & Taste & Odor & Texture & Appearance \\
\hline Control & $8.4 \pm 0.52$ & $8.7 \pm 0.71$ & $8.8 \pm 0.63$ & $8.5 \pm 0.71$ & $8.3 \pm 0.67$ \\
\hline $\begin{array}{c}\text { LFR } \\
0.25 \% \\
0.50 \% \\
0.75 \% \\
\text { LSD }(p<0.05) \\
\end{array}$ & $\begin{array}{c}9.2 \pm 0.63 * * * \\
8.9 \pm 0.95 * \\
8.9 \pm 0.68 * \\
\mathbf{0 . 3 3}\end{array}$ & $\begin{array}{c}8.9 \pm 1.05^{*} \\
8.4 \pm 1.01^{*} \\
7.9 \pm 1.11^{*} \\
\mathbf{0 . 3 9}\end{array}$ & $\begin{array}{c}8.8 \pm 0.83 * \\
8.8 \pm 1.03 * \\
8.6 \pm 1.17 * \\
\mathbf{0 . 1 1}\end{array}$ & $\begin{array}{c}8.7 \pm 1.06 * \\
8.9 \pm 1.10 * * * \\
9.2 \pm 0.62 * * * \\
\mathbf{0 . 3 0}\end{array}$ & $\begin{array}{c}8.8 \pm 0.92 * * * \\
8.7 \pm 0.82 * \\
8.9 \pm 0.32 * * * \\
0.26\end{array}$ \\
\hline \begin{tabular}{|c|} 
CFR \\
$0.25 \%$ \\
$0.50 \%$ \\
$0.75 \%$ \\
$L S D(p<0.05)$
\end{tabular} & $\begin{array}{c}9.0 \pm 1.03 * * * \\
8.5 \pm 1.06^{*} \\
8.7 \pm 1.14^{*} \\
\mathbf{0 . 2 6}\end{array}$ & $\begin{array}{c}7.8 \pm 1.09 * \\
8.2 \pm 1.32 * \\
8.9 \pm 1.09 * \\
0.50\end{array}$ & $\begin{array}{l}8.9 \pm 0.74 * \\
8.6 \pm 1.07 * \\
8.7 \pm 1.16 * \\
\mathbf{0 . 1 3}\end{array}$ & $\begin{array}{c}8.9 \pm 0.88 * * * \\
8.8 \pm 1.03 * \\
9.5 \pm 0.71 * * * \\
\mathbf{0 . 4 2}\end{array}$ & $\begin{array}{c}8.6 \pm 0.70 * \\
8.9 \pm 0.57 * * * \\
9.5 \pm 0.71 * * * \\
0.51\end{array}$ \\
\hline
\end{tabular}

The values are mean of 10 panelists $( \pm \mathrm{SD})$.

$*$ Non-significant $\quad * *$ Decrease significant $\quad * * *$ Increase significant

\section{Microbiological quality of yoghurt with legumes derivatives:}

The microbiological analysis proved that yoghurt produced using flour (Table 6) increased the total bacterial count $101 \%$ by lupine protein concentrate (LPC) $(0.25 \%)$. In the same while, CPC $(0.25 \%)$ concentration increased the yeast and mould by $103 \%$ compared to control. All the concentrations of LPC and CPC showed no coli group. This may be due to the effect of heat treatment of milk mixes.

Table (6): Microbiological analysis of yoghurt produced with using sweet lupine LPC and chickpea protein concentrate CPC

\begin{tabular}{|c|c|c|c|}
\hline Treatment & $\begin{array}{c}\text { Total bacterial } \\
\text { count (cfu/g) }\end{array}$ & $\begin{array}{c}\text { Yeast and } \\
\text { Mould(cfu/g) }\end{array}$ & $\begin{array}{c}\text { Coli form } \\
\text { group(cfu/g) }\end{array}$ \\
\hline Control & 9000 & 3200 & ND \\
LPC & 9100 & 2000 & ND \\
$\mathbf{0 . 2 5 \%}$ & 8800 & 1500 & ND \\
$\mathbf{0 . 5 0 \%}$ & 8600 & 1100 & ND \\
$\mathbf{0 . 7 5 \%}$ & 8700 & 3300 & ND \\
CPC & 8400 & 3100 & ND \\
$\mathbf{0 . 2 5 \%}$ & 8100 & 2900 & ND \\
$\mathbf{0 . 5 0 \%}$ & & & \\
$\mathbf{0 . 7 5 \%}$ &
\end{tabular}

cfu= colony forming unit

$\mathrm{ND}=$ Non detected

The microbiological analysis proved that yoghurt produced by different concentrations from protein isolates (Table 7) had less counts for yeast and mould and total bacterial count at the different concentrations of LPI and CPI. All of the concentrations of LPI and CPI showed no coli group, and that may be due to the milk heat treatment.

The present work showed the high quality of protein isolate of sweet lupine and chickpea. For their also high solubility and safety, it was recommended using them in yoghurt industry as additives at the rate of 0.25 or $0.50 \%$ according to the requirements

Fayoum J. Agric. Res. \& Dev., Vol.20, No.1, January, 2006 
PREPARATION AND EVALUATION OF YOGHURT.

Table (7): Microbiological analysis of yoghurt produced with using sweet lupine LPI and chickpea protein isolate CPI

\begin{tabular}{|c|c|c|c|}
\hline Treatment & $\begin{array}{c}\text { Total } \\
\text { count }(\mathbf{c f u} / \mathbf{g})\end{array}$ & $\begin{array}{c}\text { Yeast and } \\
\text { Mould(cfu/g) }\end{array}$ & $\begin{array}{c}\text { Coli form group } \\
\text { (cfu/g) }\end{array}$ \\
\hline Control & 9000 & 3200 & ND \\
LPI & 8400 & 2500 & ND \\
$\mathbf{0 . 2 5 \%}$ & 8100 & 2100 & ND \\
$\mathbf{0 . 5 0 \%}$ & 7900 & 1800 & ND \\
$\mathbf{0 . 7 5 \%}$ & 8300 & 2300 & ND \\
CPI & 8000 & 1900 & ND \\
$\mathbf{0 . 2 5 \%}$ & 7400 & 1700 & ND \\
$\mathbf{0 . 5 0 \%}$ & $\mathbf{0 . 7 5 \%}$ & &
\end{tabular}

$\mathrm{cfu}=$ colony forming unit $\quad \mathrm{ND}=$ Non detected

\section{REFERENCES}

Al-Zaid, M.M.; Hassan, M.M.; Badir, N. and Gumaa, K.A. (1991): Evaluation of blood glucose lowering activity of three plant diet additives. J. Pharmocognosy, $29: 81-88$.

AOAC (1995): Official Methods of Analysis. Association of Official Analytical Chemists, Kenneth Helrich, $16^{\text {th }}$ ed., Virginia, 2220 USA.

Bencini, M.E. (1986): Functional properties of durm-dried chickpea (Cicer arietinun L.) flours. J. Food Sci., 51: 1518-1521.

Berot, S. and Davin, A. (1996): Technologie Dextraction et de Purification des Matieres Proteiques Vegetables. In B.Godon (Ed.), Protien vegetables, Paris: Technique and Documentation Lavoisier. [C.F. Food Chem., 1999, 64: 237243].

Difco (1985) : Difco Manual: Dehydrated Culture Media and Reagents for Microbiological and Clinical Laboratory Procedures, $10^{\text {th }}$ ed. Difco Laboratories, Detroit, Michigan, USA.

El-Adawy, T.A. (1986): Chemical and technological studies of faba bean seeds. M.Sc. Thesis, Food Tech. Dept., Fac. Agric., Minufiya Univ., Egypt.

El-Naggar, S.A. (1997): Enzyme and chemical modification of lupine seed proteins. M.Sc. Thesis, Food Sci. and Technol. Dept., Fac. Agric., Minufiya Univ., Egypt.

Eskander, E.F. and Jun, H.W. (1995): Hypoglycemic and hyperinsulinemic effects of some Egyptian herbs used for the treatment of diabetes mellitus (type II) in rats. Egypt. J. Pharma. Sci., 36: 311-342.

Gomez, K.A. and Gomez, A.A. (1984): Statistical Procedure for Agriculture Research. John Willy and Sons Inc. USA.

Hung, S.C. and Zayas, J.F. (1992): Protein solubility, water retention and fat binding of corn germ protein flour compared with milk protein. J. Food Sci., 57: 372-379.

Hung, T. and Nithianandan, V. (1993): Preparation and evaluation of noodles supplemented with chickpea and lupine flours. Asian Food J., 8: 26-31.

Hussein, H.A. (1999): Biochemical studies on lupines and alkaloids. M.Sc. Thesis, Food Sci. Dept., Fac. Agric., Cairo Univ., Egypt.

King, J.; Aguirre, C. and De-Pablo, S. (1985): Functional properties of lupine protein isolates (Lupinus albus cv. Multolupa). J. Food Sci., 50: 82-87.

Lee, C.M.; Whiting, R.C. and Jenkins, R.K. (1987): Texture and sensory evaluation of frankfurters made with different formulations and process. J. Food Sci., 52: 896-901.

Fayoum J. Agric. Res. \& Dev!, Vol.20, No.1, January, 2006 
Ashraf I. Nagib, et al.,

Luck, T.; Waesche, A.; Borcherding, A.M.; John, G. and Mueller, W.D. (1995): Protein preparations made of sweet lupines. Fleischwir-tschaft, 75 (11): 13051310.

Metry W.A.; A.I. Nagib; E.M. El-Hadidy (2003): Some chemical, physical, microbiological and organoleptic properties of ice cream produced by using some legumes or their derivatives. J. Home Economics, Minufiya Univ., 13 (2): $115-135$.

Millan, F.; Alaiz, M.; Hernandez, P.I., Sanchez, V.R. and Bautista, J. (1995): Study of neutral lipids of Lupinus mutabilis meal and isolates. J.A.O.C.S., 72 (4): 467-471.

Mohamed, A.A. and Duarte, P.R. (1995): Composition of Lupinus albus. Cereal Chem., 72: 634-647.

Saldamli, I.; Vrijhoef, A. and Temiz, A. (1991): The stability of aspartame in yoghurt. J. Dairy Sci., 19: 249-255.

Smith, F. (1969): The Chemistry of Plant Gums, Mucilages and Some Related Polysaccharides. A.C.S. Monograph Series, Reinhold Pub. Corporation, Chapman and Hall, LTD, London.

Snedecor, C.W. and Cochran, W.C. (1973): Statistical Methods $6^{\text {th }}$ ed. The Iowa State Univ., Amer. Iowa, USA, p. 534.

Sobihah, T.Y. (1998): Utilization of some vegetables proteins and cheese whey in manufacturing weaning foods. M.Sc. Thesis, Food Sci. and Technol. Dept., Fac. Agric., Minufiya Univ., Egypt.

Youssef, G.M. (1999): Effect of processing on antinutritional factors and biological value of major legumes. Ph.D. Thesis, Food Sci. Dept., Fac. Agric., Cairo Univ., Egypt.

Fayoum J. Agric. Res. \& Dev., Vol.20, No.1, January, 2006 